\title{
Deconstructing Sustainability Perceptions: Investigating Technological Innovation-Environmental Interaction in Green Buildings and the Influence of Architectural Design
}

\section{Stephen Poon}

Integrated Sustainability \& Urban Creativity Centre, Asia Pacific University of Technology \& Innovation, Technology Park Malaysia, Bukit Jalil, 57000 Kuala Lumpur

\begin{abstract}
Sustainability principles impact green building infrastructure design, planning and construction decisions. The influence of social perceptions in transforming notions of green architecture and sustainable designs as desirable are also interesting contexts for urban design researchers in addressing environmental impacts. The aim of this paper is to discuss a breadth of available literature on architectural sustainability, and the many effects of urbanisation. Few scholars have attempted to frame qualitative discussions of sustainability perceptions with regards technological interaction with built environments. Research utilises two green building design frameworks to analyse differences between sustainability perceptions of innovation and environmental design aesthetics, namely technological innovation interaction with architecture, and architectural design interaction with nature. Findings from case studies of three examples namely The Port of Portland, The Pompidou Centre Paris, and Frank Lloyd Wright's First Unitarian Society are deconstructed using qualitative approach to demonstrate that while architectural interaction with nature is viewed as ideal characteristics, green building design innovations with technological interactions play a larger role in influencing social perceptions towards sustainability. Findings suggest that green buildings should encompass a wider range of aesthetic-based designs, from passive ventilation to lighting systems and materials, but in order to sustain positive stakeholders' perceptions, social benefits and education among green building policymakers, designers and architects is crucial. Recommendations on how to cultivate a balance in pragmatic, cost-conscious approaches, including interactions with technologies, will be discussed in conclusion.
\end{abstract}

\section{Article History}

Received : 02 June 2020

Received in revised form : 21 October 2020

Accepted : 07 December 2020

Published Online : 31 December 2020

\section{Keywords:}

Sustainable Architecture, Environmentally Sustainable, Architectural Design, Green Building, Technological-environmental Interaction

\section{Corresponding Author Contact: \\ stephen.poon@apu.edu.my}

DOI: $10.11113 /$ ijbes. v8.n1.621

\section{Introduction}

A Every building is sited within an environmental context, producing effects and being impacted upon by its users, occupants, other buildings, its surroundings and society.
Sustainability is the art of living while negotiating the ability of future generations to partake in the same assertions through smart resource management and utility (Brundtland Report, 1987: p.49). Sustainable concepts are defined on the three interlocking aspects of economic, social and environmental 
performance. Known as the Three Sustainability Pillars (Figure 1), these aspects are imperative in satisfying and fulfilling the Brundtland Commission Report (1987) principles calling the circular ecology model an enabler for economic and environmental goals, achieved through equitable policymaking, utilisation, consumption and management of resources and capital, while at the same time, producing positive long term benefits, thus safeguarding the social wellbeing of communities and nations (Circular Ecology, n.d.).

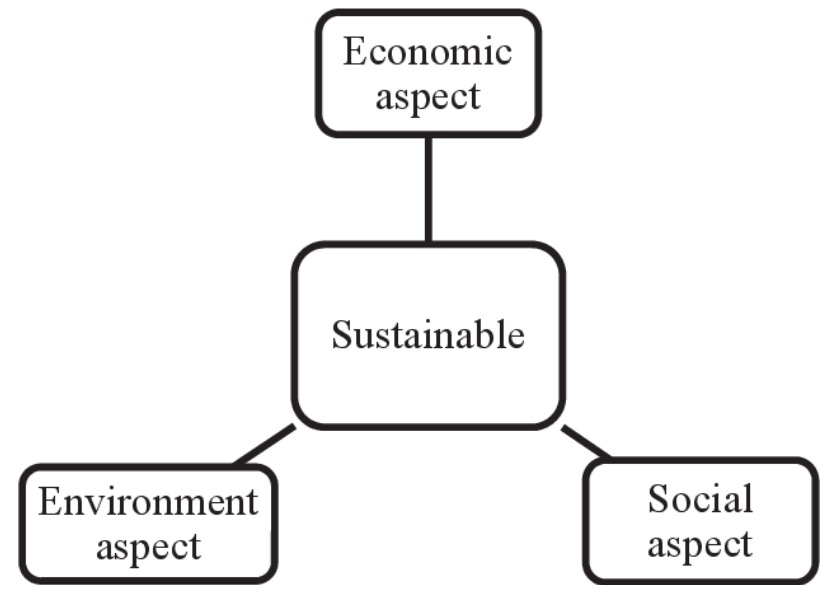

Figure 1: The Three Sustainability Pillars

Using the Three Sustainability Pillars, sustainable architecture could be defined as the systematic processes involving interdisciplinary collaboration to research, plan, design, implement, operate, manage and maintain construction sites, projects, buildings, landscapes and spaces, co-mingling a host of criteria that improves building performance such as aesthetic design, quality of indoor air, lighting and heat, impact on ecology and the surrounding environment, optimisation of social contact, human productivity and wellbeing, ensuring security, viability of economic value through minimising energy costs, delivering and enhancing investment value to stakeholders (Thompson and Sorvig, 2008). These are evaluated via assessment metrics, indices, rating systems or guidelines developed by industrial bodies, certification agencies and institutions (Brophy and Lewis, 2011; Horman, et al, 2006; Lowe, 2010; Trencher et al, 2016; US Chamber of Commerce Foundation, 2017; Woolley et al, 2005; World Green Building Council, n.d.).

\subsection{Statement of the Problem \& Research Questions}

The recent decades have seen a groundswell of passionate advocacy as well as fierce criticisms towards the green building design agenda, whichever side of the debate one chooses, the resulting verdicts and studies seem to infer that social awareness on the ecological impact of urbanisation has heightened. The issue is positioned on how green designs achieve greater potential outcomes for climate change response and adoption of solutions that substantially mitigate climate change conditions such as resource depletion. Adjunct to this debate has been the architectural and construction industries' driving force to transform and improve perceptions of the sustainable built architecture movement. The influence of liveability characteristics has led some authors to theorise that the green architecture movement is orientated to favour perceptions of technological innovations as the preferred spatial solutions, rather than a myriad of variable factors, such as cultural heritage or safe, neighbourhood ambiance (Leeuwen and Timmermans, 2006: pp.393-395).

It is interesting to inquire whether there is more to green building design approaches than merely adopting technologies and innovative systems in the industry's feverish phase of ecoconsciousness. Research questions guiding this paper include: What main factors influence perceptions of sustainable architecture? Does technological-environmental design interaction create positive perceptions towards green building design by integrating social and economic benefits such as stakeholder perception of market valuation and investment returns?

To understand current perspectives on sustainability practices for urban buildings, a scope of relevant factors to illustrate the importance of sustainability principles, will be reviewed. Case examples will investigate green building design interaction with nature, and architecture's interaction with technology. The analysis of findings synthesises these perceptions in order to develop objective recommendations and help readers grasp the scope of issues under discussion.

\section{Literature Review}

As green-conscious trends become de rigueur among urban society, architectural scholars suggest there are definitive correlations between ecological-health with the desire to live, work and thrive in healthy spaces. Sustainability manifests in architectural forms through optimisation of resources from nature, while others incorporate bioclimatic and green material principles, energy-saving, passive systems and flexible construction. Although designed to mitigate environmental impacts, such buildings may turn out to be conventional in its aspirations.

Lowe (2010: pp.57-60) explains why designers need to communicate their beliefs about "aesthetic sustainability" in planning green buildings to ensure long term benefits to health, security, comfort and order. These involve perceptions of functionality and aesthetics in constructing, refurbishing or remodelling existing buildings. Sustainability perceptions thus frame the basis of urban architectural research in understanding the scope and potential of green buildings reflective of circular ecology systems, but a critical challenge to address is the lack of standards definitions of sustainable building design performance, in short, what determines "green-ness" of structures, landscapes and spaces which transfers research data into high performance in actual conditions. Researchers are concerned that sustainability practitioners pick out isolated features to represent the architect or designer's vision, instead emphasising on "whole-building approach" to assessing high performance 
environmental design (World Green Building Council, n.d.; Zainordin et al, 2018).

A scope of performance indicators, technical specifications and assessment tools exist to provide frameworks such as USCBC, LEED and WGBC that define design sustainability, yet Horman et al (2006: p.138), in the inaugural Journal of Green Building, contend that these are not always comprehensively integrated buildings, facilities, landscapes and built environment projects since "actual conditions on site demand more useful and pragmatic solutions" beyond planning and lifecycle analysis. As the authors explain, there must be closer application of environmental research findings to social and economic impact through mapping its scalability, guidelines for tracking performance, knowledge transfer for future value enhancement.

Curwell, Deakin and Symes (2005: pp.432-442) exposed some shortcomings in perceptions towards aesthetics value of green buildings. Using the Settlement Model to examine the context of designing "high quality living and working environment" as the basis for architecture's ecological response, the authors uncovered surprisingly unfavourable factors, including the longterm management costs of green infrastructure, e.g. waste management systems, interior and exterior climate control strategies, contribution to health, maintenance of landscaping, market and investment evaluation of green building as high-yield property.

The achievement of broader environmental objectives through sustainable architecture is often contentious. A green roof, for instance, integrates a building more closely to the landscape, but its efficiency and performance is negated if the added weight of roofing affects its long-term structural strength and durability. The cost of "reasonable maintenance" is another green design factor that has been discussed by landscape academics, who argue that reduction in energy use costs less that constant replacement (Thompson and Sorvig, 2008: p.334). Recognised green building certifications, with proper monitoring of policy and regulatory adherence, added with guidance by environmental agencies, engineering and built construction experts, play a crucial role in overcoming barriers to green building adoption (Chan et al, 2017).

This was affirmed by a case study in Indonesia on the exactitude of stakeholders' knowledge by Universitas Indonesia civil engineering academic Prof Mohammed Ali Berawi et al (2019). The authors' findings show that while social and economic benefits were valued factors in green building rating systems adoption, the lack of environmental knowledge by building owners and investors themselves are a key hindrance in communicating sustainability project proposals by green building councils to the government.

An ecological standpoint by William McDonough and Michael Braungart who crafted "The Hannover Principles" in 1992, insist on addressing waste as crucial by-products of the human-nature coexistence paradigm in their manifesto, Cradle to Cradle (2002). Waste is an inevitable outcome of large-scale mass manufacturing for industries, as products are designed on a linear, cradle-to-grave model; resources extracted for singular products, producing waste pollution and environmental damage perpetually. Marcus Fairs (2013) puts it this way: "Green's message [has fallen] foul of the law of diminishing returns once you've hewn furniture from raw timber, there's not much further you can go". As a social response, Fairs (2009: p.10) notes the trend among younger designers to revert to, and experiment with, low-tech design ideas to improve lifestyle and wellbeing, from urban farming, repurposing used materials for accessories, furniture and interior decoration.

Groat and Wang (2013: p.4) link current research interests in urban sustainable architecture to the "shifting tides" of socioeconomic pressure, involving closer orientation of critical theories of architectural experiences to social realities. Citing work by Kevin Lynch (2000), The Image of the City (2013: pp.5070 ), the process of living is said to be connected to the way individuals develop perceptions and orientations on the familiar forms of urban cities. Perception studies find that to gain import and positive perceptions, ideal characteristics of green design which must be visible include being "cost-effective", "easy to implement", "beneficial to health and wellbeing (e.g. comfort and convenience)", "boost for productivity" and "user-friendly" to its occupants, rather than oriented towards conserving nature (Baird, 2014).

At the same time, critics argue that incentivisation through taxation to encourage the production of green materials does not necessarily lead to accelerated adoption, nor stimulate the construction sector to recycle waste or reduce energy usage in processing industrial products (Boostra, Rovers and Pauwels, 2000; van den Bergh and Janssen, 2004; Woolley et al, 2005). More pragmatic measures are the initiatives by social movements to promote circular solutions which serve community needs through for-profit recycling, repurposing and up-cycling practices such as glass processing, metal recovery, and waste composting (US Chamber of Commerce Foundation, 2017).

While idealist notions of sustainable buildings have sustained academic debates for decades, there are specific challenges for populations in developing regions. Socioeconomic forces necessitate a push for rapid urbanisation, with ecological agendas taking a backseat as the consequence. Santosh Ghosh (cited in Boonstra et al, 2000) notes that with millions from lowerincome Asian societies demanding urban housing, local authorities have to seek solutions beyond environmental protection and ecological awareness when considering sustainable architecture. Awareness maybe well-grounded; reality, however, could well be different (WBDG, 2016).

Environmental designs inspired by minimalist abstractions such as centralised grids and designated walkways, instead of promoting communal ties, are often inaccessible to certain segments such as the disabled or senior citizens, contributing to the disintegration of traditional geosocial structures (Boonstra et al, 2000). Green design advocates urge for more effective implementation of urban environmental management policies and plans by examining the feasibility of ecological solutions and 
resources which ensures social inclusiveness of urban spatial design (Czerwinska, 2017; Hanson, 2004). In this regard, urban planners, agencies and experts need to mandate a strong financial case for green building design to promote the concept of long-term urban sustainability. Woolley et al (2005) notes that image perceptions towards sustainability are formed from the tangibility of designs of infrastructures for commercial buildings.

In the pursuit of green design models, positive perceptions on how the building developer or owner improves usage efficiency of electricity and water and practices conservation, play a practical role in incentivising green practices.

Architectural researchers Groat and Wang (2013) note that advanced technological innovations implicate huge financial outlay of capital, in particular, spending or funding of initial $\mathrm{R} \& \mathrm{D}$, but if fundraising processes lack transparent disclosure or traceability, the scale and costs of maintenance, structural upkeep and repairs increases, raising stakeholders' doubt and resistance to adoption of green buildings. On a larger scale, innovations used in commercial building designs should be representational of the long-term goals of stakeholders. Environmental impact assessments on technological use must be laid down early before deciding whether "to build new or convert an old building or whether the activities need a building at all" (Woolley et al, 2005: p.20). In sum, literature shows that sustainability perceptions hinge on the ability of planners, architects and designers to present the standpoint of enablement that green buildings purportedly deliver (Baird, 2014; Cooke et al, 2006; Zainordin et al, 2018). Barriers to green building design and technological innovations must be addressed early, and baseline perceptions on the socioeconomic and environmental benefits established, framed, understood and interpreted clearly by both authorities and professionals certified in sustainability architecture.

\section{Methodology}

As design researchers' role span beyond the confines of producing empirical data as architectural design scholarship should aim to collect, deconstruct analyse and benchmark evidence demonstrating how people adapt to living in buildings. Qualitative research highlights various aspects of green design's role in architectural innovation, expanding our understanding of sustainability perceptions (Groat and Wang, 2002).

\subsection{Case Study Methodology for Sustainability Design Research}

The As Yin (1994: pp.77-78) treats case study as an "instrumental" tool for generating theory; this may gain favourable grounds among empirical researchers who are keen to identify aggregation of categorical data and look for consistent patterns of filters which makes sustainable designs significant in practice. Stake (1995) mindfully refers to case studies from the field as mainly "naturalistic" primers, a good approach in formulating social policy and for teaching practical design theories and principles. On the other hand, where narrative cases and ethnographic fieldwork presupposes the importance of unique descriptions to capture phenomenological scopes and to derive meanings from ideal conditions, empirical researchers seek broader behavioural and contextual scopes on which they can isolate sustainability conditions and to put meanings into them.

Furthermore, case study approaches, according to Yazan (2015), are helpful to diversify and complement educational perspectives towards the subject of research; as a qualitative analysis tool, case studies collates a vast array ideas instead of merely mapping out theories to fit the designed purpose of social science research.

Beyond discussions of rationales for green built environments, qualitative case study research methodology allows for a more critical evaluation of the wider influence of stakeholder interests. However, the issue of replicability of qualitative case studies is a downside; every green project is developed based on unique geo-social factors; commercial green buildings cannot be deconstructed using similar assessment factors. Cooke et al (2006) clarifies that perceptions of costs, market valuation and long-term objectives of green buildings must be communicated to stakeholders before alternative energy technologies (AET) are adopted. Assessment of what makes for green architecture may thus be derived from case study information, which may implicate future decision-making. Notwithstanding empirical investigations of sustainability, the social and economic incentives play a very important role in investment considerations for green projects (Groat and Wang, 2013; Berawi, 2019; Yazan, 2015).

To understanding the dynamic interaction between sustainability, ecological, social and technological outcomes for this paper, qualitative research is used to produce a broader framing of perspectives through analysing technological innovations integration into building designs, and how these could be perceived by stakeholders (Cooke et al, 2006).

The role of sustainability can also be viewed through passive energy conservation strategies, by exploring spatial design for cultural information transfer and aesthetics purposes. Technological innovation will be evaluated for effectiveness in enhancing ambient quality. Findings from the three case examples will be synthesised in the Discussion section to better understand the specific implementation challenges identified in earlier research questions.

\section{Analysis and Interpretation of Case Study}

Technology has become a crucial driver in the development of modern buildings. Research affirms the progressive shift to technological use as an increasingly critical method to research, plan and implement environmental design sensibilities over several decades of architectural innovations since the 1960s (Curwell et al 2007, Reed and Lister, 2014). Fields of technological knowledge such as service engineering which studies, designs and implements the installation of service systems, adds value to building users or occupants, for instance, in introducing green lifestyle features that lowers carbon 
footprint and brings convenience, such as smart access systems for residential homes and offices, and close-circuit monitoring to boost security.

\subsection{Case Study I: Technological Interaction with Architecture}

Fields methodologies already in use range from digital mapping of processes and patterns of spatial construction (van Leeuwen and Timmermans, 2006); documenting systems and techniques of building and landscape conversion for urban regeneration through 3D modelling (Hanzl, 2007); Geographic Information System (GIS) modelling to study socio-spatial conditions and geodesign impact on the urban economy (Roche, 2014); and studying the linkages between community health and the environment (Boonstra et al, 2000). Imperiale (2000: p.31) views digital mapping as a technological representation of real topologies, with the research attempting to connect relationships between surface elements such as buildings and grounds, with human activities shaping them.

Imperative to understanding technology-architecture interaction is the shift from performance ratings to descriptive appreciation and perceptions of eco-design via educating society, investors, homebuyers and authorities on technologies which improve waste and renewable energy management (Curwell et al, 2007: p.114). Although technology enables, designing the total environment must also consider the indirect impacts on building occupants.

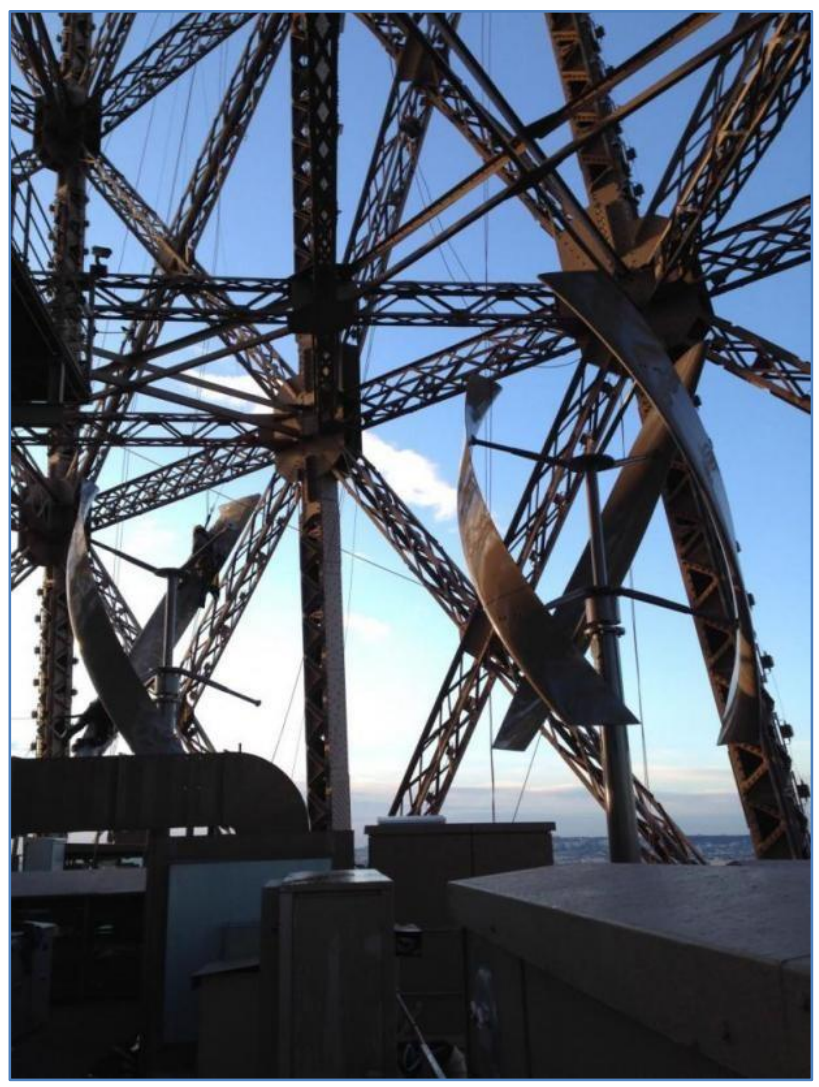

Figure 2 Eiffel Tower wind turbines
Studies on infrastructural, material, geophysical and urban ecology show evidence of beneficial outcomes from urban architecture's trans-disciplinary forms. Hence, technological interaction with ecological knowledge and cultural spaces offers a wide scope of cross-disciplinary research and interesting blending of knowledge through critical approaches to create adaptable, resilient and flexible urban systems (Reed and Lister, 2014).

High towers were once built chiefly to publicly demonstrate the application of Newton's gravitational laws. The phenomenon itself is encapsulated in these mega-structures. Eiffel Tower (Figure 2) is a complex and high-tech piece of architecture, engineering and art conjoined a recognisable icon of architectural technology and tourism place-making. In 2015, the tower embraced a green ethos by being retrofitted with a renewable energy generator using twin wind turbines worth US $\$ 490$ billion to generate $10,000 \mathrm{~kW} /$ hour of electricity, along with other methods of lowering environmental impact including rainwater collecting system, solar panels and LED lights (Scientific American, 2015).

One Another example is cited by Yudelson and Meyer in The World's Greenest Buildings (2013: p.226), is The Port of Portland in Oregon, United States (Figures 3 and 4). Through obtaining sustainability recognition under Leadership in Energy and Environmental Design (LEED) certification, architectural leadership and stewardship are demonstrated via the building's sustainable design ecosystem, spread within the 1.4 mil square feet of office headquarters comprising 10-storeys of office space.

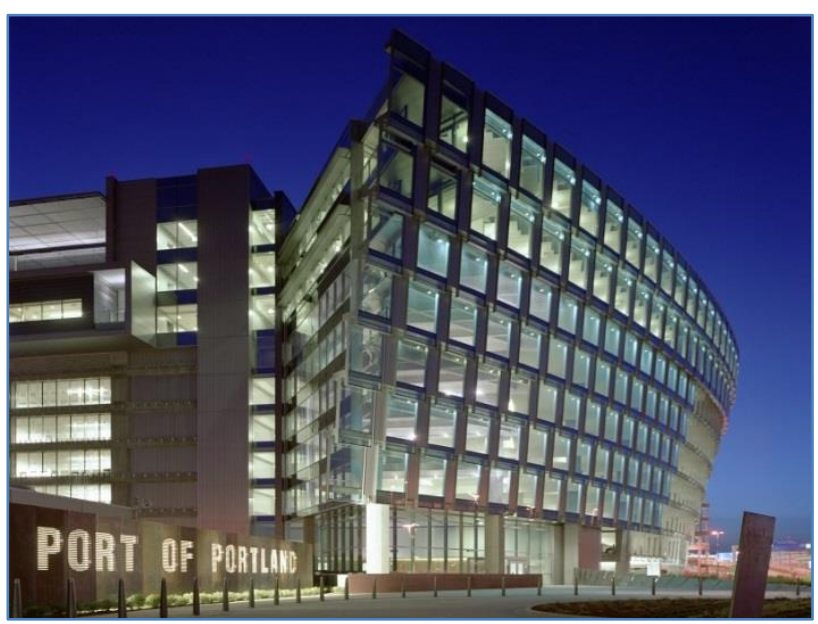

Figure 3 The Port of Portland headquarters, inspired by the hull of a ship

The Port of Portland was constructed to apply strategic longterm energy conservation measures include the 'Living Machine' series of wastewater tanks designed to treat and recycle wastewater through organic action of microorganisms. The headquarters also features a renewable heating and cooling system using 200 geothermal wells that pump warm or chilled water through radiant heating panels (depending on the time of year), an alternative energy technology (AET) which drastically lowered the occupants' dependency on regular air-conditioning (Halbersberg, 2012). Additionally, natural daylighting and smart 
sensor lighting, besides reflective glaze coating to minimise heat absorption enables efficient usage of resources. ZGF Architects designed a prominent façade that heightens the essence of its beautiful structure: a curving lapped-glass curtain wall, inspired by a ship's hull (shipping being one of Portland's historicallyimportant economic thrusts); while an open floor plan and large windows on all the ten levels provides wide vista views of the outside, creating visual unity of the organisation's heritage, business mission and future purpose (O’Brien, 2011).

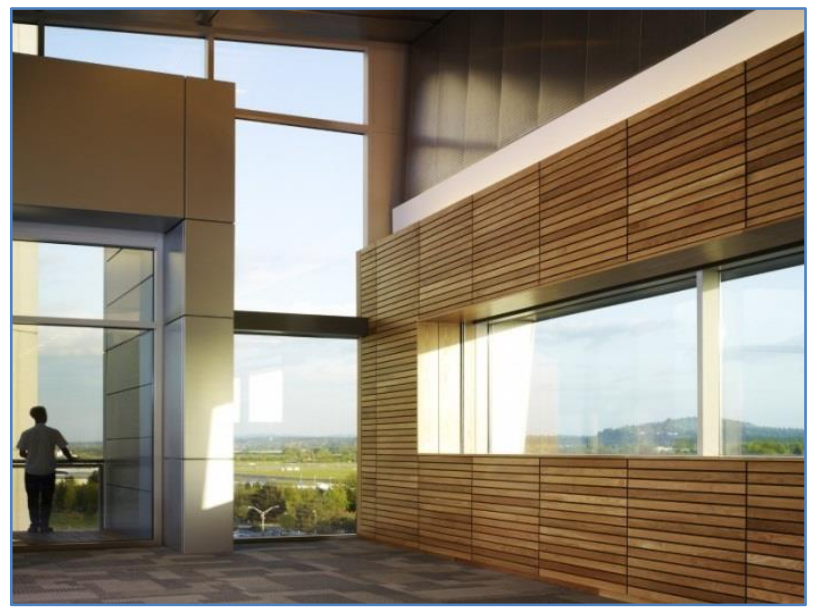

Figure 4 Daylighting is a green building feature at the Port of Portland

The Port of Portland constructed long-term energy conservation measures include the 'Living Machine' series of tanks designed to treat and recycle wastewater through organic action of microorganisms. It also built a renewable heating and cooling system using 200 geothermal wells that pump warm or chilled water through ceiling radiant panels (depending on the time of year), which drastically lowered dependency on regular airconditioning (Halbersberg, 2012).

Additionally, natural day-lighting and smart sensor lighting, besides reflective glaze coating to minimise heat absorption enables efficient usage of resources. Award-winning ZGF Architects designed a prominent façade that heightens the essence of its beautiful structure: a curving lapped-glass curtain wall, inspired by a ship's hull (shipping being one of Portland's historically-important economic thrusts); while an open floor plan and large windows on all the ten levels provides wide vista views of the outside, creating visual unity of the organisation's purpose (O’Brien, 2011).

\subsubsection{The Centre Pompidou}

High The Pompidou Centre of Art and Technology in Paris offers the potential of a highly flexible design by applying hightech materials and construction innovation in enriching the narrative evolution of architectural ingenuity through the art of engineering, invention and technology. Acting as a national French cultural centre, the Pompidou's architectural aesthetics, designed by Renzo Piano and Richard Rogers, is expressed in its dramatic infrastructure visibility, with the use of visual mapping techniques to expose a buildings "insides" using material effects such as steel beams, electricity lines, water pipes, air ducts and elevators (Figures 5 and 6). The Pompidou's purported energy efficient design reduces the need for regular wall skin and external wrapping (Meyers, 2011). Murphy (2012: p.84) further points out that the Pompidou's rather naïve techne was a 1960s social conjecture for "solutionism", a shift from the previous era's elitist architectural classicism to avant-gardism. Hence, the approach is complementary of its intended purpose as an art and cultural centre. Concurring with this notion, built environment academic Francesco Proto (2005) wrote a critique arguing that the objectification of the Pompidou, through its overt display of a building's insides as fetishistic, which has led many in the field of urban design to perceive sensationally innovative architecture as performing a "ritual of transparency", when it actually masks its potential to be a futuristic architectural form.

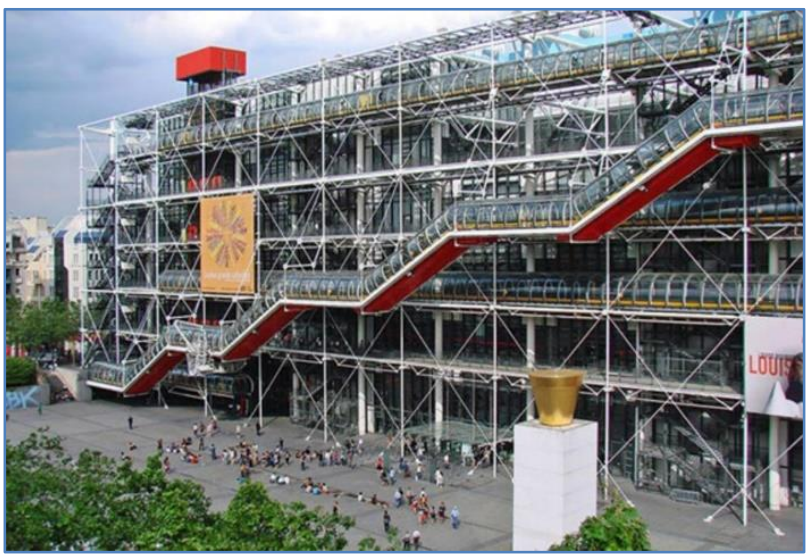

Figure 5 Exposed façade of The Pompidou Centre in Paris, with its elevator and interior design turned out

The dematerialisation of sustainability is expressed via 'megalomaniac' symbols throughout its 7,500 sq. metre-floor space to represent mass notions of "liberty" and "freedom" with features such as an escalator snaking around the blatantly exposed glass façade. The interior is coated to emit artificial lighting at night, becoming its frames of recognisable fame, and an intentional representation of utopian mainstream characteristic of social equality by de-materialising the relationships between environmental space and society. Further signifying the separation of space from audiences, the building invites a spectator's response by being nothing more than a surface spectacle (Imperiale, 2000: p.22) with media screens seducing viewers with apparent importance, and various cinema screening activities, performance spaces and museum exhibitions projecting what its architect Piano called as both the "known and yet to be discovered knowledge" of society (The Centre Pompidou, n.d.).

The Pompidou Centre continues to pull urban design theories apart. Its hyper-modern structure demystifies technology as a necessarily 'hidden' aspect of modern architecture (Proto, 2005). The architectural design of the Pompidou signifies the perception that transparency is the acceptable standard for postmodernist society, by presenting a seemingly a less elitist and more equitable urban structure, that is unrepeatable as much as it is flexible. 
Nevertheless, turning a building inside out to showcase the "gears at work" on the inside, is a reminder of the selfobjectification of human society, and makes the building a shrewdly invisible machine that breaks the natural law of reason by inverting innocent individuality and our sacred relationship with nature, into one of arrogant visibility (Porto, 2005: pp.586-587).

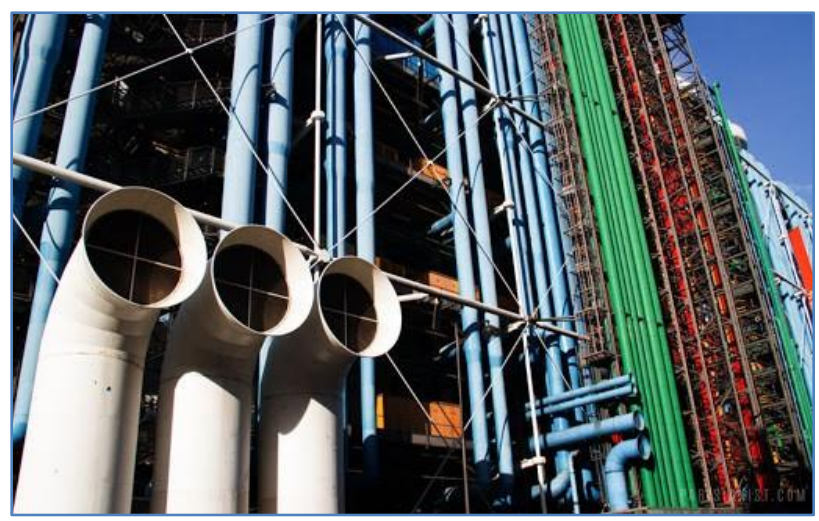

Figure 6 The Centre Pompidou to represent water (green), electricity (yellow), air circulation (blue) and people (red)

\subsection{Case Study II: Architectural Design Interaction with Nature}

Aesthetics of built design also derives from the symbiosis between structural (rational) and emotional concepts of bioregionalism (Sim van der Ryn, cited by Lowe, 2010: 66), which states the holistic "harmony of many goods", utility, durability and beauty, as underpinning ecological design principles. The approach of "working alongside or cooperating with nature" is a common perception of ecological design, involving exploration of spatial and emotional connections between ourselves and the aesthetics of natural surroundings via material, surface and structural analysis, and how nature as an external entity impacts place-making in the study of urbanism (Chapman and Gant, 2012; Chatterjee, 2014; Dovey, 2010; Lowe, 2010; van den Bergh and Janssen, 2004).

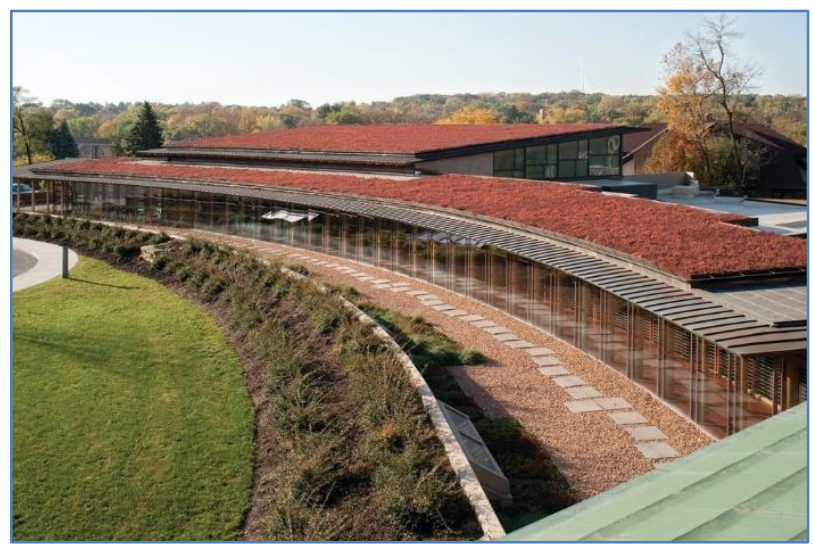

Figure 7: First Unitarian Society Meeting House with green roof design by Wright
Since 1990s, contemporary architectural and environmental design research has seen a greater focus on phenomenological experiences where cultural heritage value forms a key perception of building architecture, involving the study of social behaviours, characteristics and the emotional outcomes of living surroundings which makes places sustainable as community landmarks (Boonstra et al, 2007; Groat and Wang, 2013).

A pioneering example is found amongst American architect Frank Lloyd Wright's built legacies. The First Unitarian Society of Madison (FUS) Meeting House (Figure 7), completed in 1951, located in Wisconsin, was literally topped with a green roof, with solar panels installed on the flat sections to harness passive solar power corresponding to the direction of the sun, generating 90,000 kW-hours of electricity per year. Glass serves both as its walls and windows, creating airy spaciousness and natural lighting, effects which dramatically heightens the prow (front) section of the 500-seat auditorium (Figure 8). Maczulak (2010: p.138) wrote an essay on Wright's characteristic attributes the "organic" method of construction as the essence of form and function working in harmony, its design, being, like nature: sloping, flowing, low-pitched, with deep overhangs and horizontal planes (omitting basements and attics), that lessen the separation of spaces between indoor and outdoor.

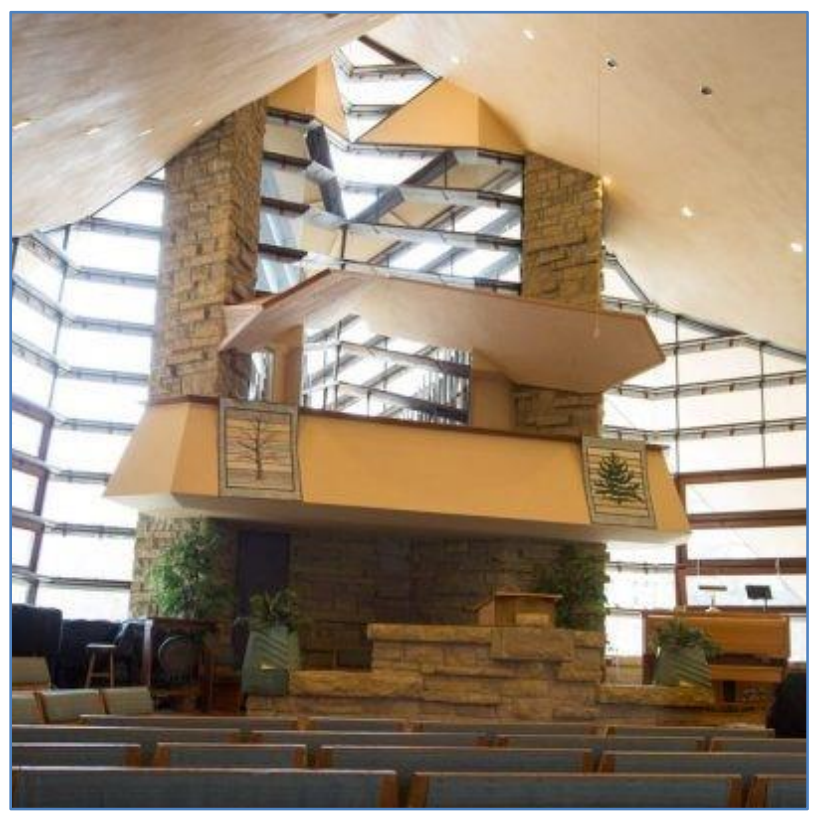

Figure 8: Unitarian Society Landmark Auditorium prow

Wooden grids between the external glass façade harmonises the indoor shades and shadows with outdoor and landscape views (University of Wisconsin, 2016). During its restoration and expansion phase in 2008, solar panels were also installed into its interior atrium wing, along with a geothermal-electric HVAC system, while the green roof was designed to attain a "carbon neutral vision" of the internal ministry team who provided management oversight of the sustainability goals. These initiatives enabled participants and the general public to be included in decision making, and via sponsorship and funding contributions (Legacy Solar Co-Op, 2019). As a result, the 
building gained a Gold LEED certification, while preserving the historic grounds of the original structure. As a symbolic representation of architectural design heritage (Wright on the Web, n.d.), the FUS shows why it continues to appeal to the American cultural imagination as an inspiring antecedent model for many $21^{\text {st }}$-century green building designs in modern urban society today.

\section{Discussion of the Findings}

The case studies presented for analysis in this paper frames a qualitative approach to indicate the importance of stakeholder perceptions, which sustainability researchers and practitioners should acknowledge. The imbalance in stakeholder involvement often results in tangled power conflicts between those who are excluded or ignored by the dominant parties such as developers and management committees (Dovey, 2007: p.29).

Pertinent questions on functionality, resource utilisation and design construction processes further underlie conflicts among stakeholders and decision-makers for green building adoption (Chan et al, 2017; Spiegel and Meadows, 2010: p.4). Undefined sustainability performance goals have produced criticisms over the real value and practicability of green buildings. In some instance, commercial or residential tenants may not be consulted or heard in the developer's choice of energy-saving modes (for heating or cooling utilities). Stakeholders may find little encouragement to adopt green designs if, for example, they are not informed or briefed about the cost benefits of passive systems such as switching off public corridor lights at nights. At this juncture, we ask, why are these cases significant in the evolution of urban architecture?

The design of the Port of Portland suggests that perceptions of innovation through technological adaptation has become the new cultural capital, a symbolic representation of social power through economic progress (Dovey, 2007). This would concur with present critical theories which theorise that sustainable buildings are symbolic of social power, an enablement for progress rather than a constraint in the process of urbanisation. The architects behind the Pompidou in Paris pushes the idealisms of aesthetic innovation, by determining flexibility of construction as a factor for long term usage diversity and functioning. In contrast, the case study of Frank Lloyd Wright's classical architecture demonstrates architectural interaction with the environment to perform the function of cultural carrier of information, but this role may no longer resonate today as urban architecture is increasingly perceived to be an interaction between art, technology and the science of building for economic returns.

When deconstructed into 'cause and effect' rationales for green building adoption, these case studies demonstrate that the ecodesign architectural discourse goes beyond determining spatiality, functionality, economic viability, valuation and efficient resource (material) consumption. They further suggest that the search for useful innovations embracing aesthetics helps to introduce better technologies for green infrastructure development practices. Ecological conservation cannot be denied or ignored, in the progress from "self-interest to global concerns" (Groat, 2002: p.117), but perceptions of sustainability are affected by and interrelated with how successfully architecture adapts and apply sustainability benchmarks to measure the efficiency of innovations, incorporated into practical use.

However, this finding indicates that sustainable architecture performance should not assume that incorporating technological innovations equal green, neither should sustainability ethos be dismissed as a passing phase in architectural development. In sustainability perceptions, the dominant view is that the physical, social and design dynamics of green buildings are the most crucial factors in determining asset valuation rather than aesthetic or environmental benefits. This suggest the gap will continue to exist between the idealisms of architectural design interaction with nature through passive systems, and technology's active role in enhancing green buildings.

There is thus a need to re-examine perceptions of green building technology as architecture's ends rather than means, which has grown notably in this century of heightened eco-consciousness. Another issue is the marketing of sustainable designs. Evidence of false or deceptive claims of fulfilling sustainability criteria based on speculative trends must be monitored and flouting developers publicly censured, especially among premium, commercial green buildings (Oyedokun, 2017).

Another factor is the increase in consumer protection mechanisms through establishing actionable laws. In this regard, industry agencies and authorities play a critical role to strengthen regulatory frameworks against unethical practices (or omissions) that use green-washing agenda such as "eco-marks", "clean technology" and other dubious labels as a marketing or publicity boost (Lane, 2011). For construction and development sectors, compliance with provisions under national green building codes of practice should be tightly monitored with concern for safeguarding users and occupants.

At the same time, professional certification must be encouraged among practitioners who intend to advise authorities and consumers on issues relating to sustainability ratings and information labelling for green building design, manufacture, efficiency, lifecycle and safety assurance (van den Bergh and Janssen, 2004). The education of green building practitioners must be a present priority among developing nations seeking global recognition for promoting urban sustainability concepts. For interior design sectors, compliance with passive design indices that are credible, accurate and comprehensive should be emphasised (Brophy and Lewis, 2011). Issues of conflict may arise as lessons are learned through acknowledging knowledge gaps, attitudinal and perception differences over the environmental advantages, aesthetics and brand image of building fitted with innovative systems and high-tech facilities. To overcome this, stakeholder issues such as barriers to technologies adoption should be transparently discussed to ensure building owners, management, occupants or users' perceptions are heard and documented (Chan et al, 2017). Sustainability perceptions also derive from designing passive 
aesthetics that "cooperates with nature". By looking closely at a range of influencing factors, a project may genuinely reflect the Three Sustainability Pillars of social, economic and environmental impacts to be holistically communicated.

\section{Conclusion}

Within the next decade, a major revolution looks certain, with improvements in sustainable technologies and practices of green construction and environmental design. Undeniable is the fact that positive sustainability perceptions could be translated into economic benefits to enhance market valuation among investors keen to consider the financial returns that green office buildings offer compared to conventional buildings in terms of rental yields and sale price (Myers et al, 2007; Oyedokun, 2017).

This research is aimed at enlarging perspectives and understanding of the role of perceptions towards technological innovations in sustainable architectural and environmental design. Architectural scholarship and debates underline practitioners' responsibility to transcend the commercial aspects of sustainable design. As more developers lay claim to green projects' social benefits through marketing green design aesthetics combined with environmental performance, green buildings seem to point the way forward for future urban design approaches. Findings strongly suggest that social perceptions on innovations influence the potential value of green architecture by embodying what stakeholders might view as pragmatic solutions for construction and material use, energy savings, usage diversity, and reduced maintenance.

Yet, as to be seen in the case of the Pompidou's brash design, the real environmental consequences may be hidden from social perceptions if the image "becomes the end rather than the means" of understanding sustainability (Dovey, 2010: p.53). Ecological innovations in architecture must be proved in their abilities to 'future-proof' building designs in order to fulfil their critical function as social enabler for sustainable growth of the human population, which sustainability designer Ezio Manzini called architecture's most noble, powerful purpose (cited in Chapman and Gant, 2012: pp.76-95).

Sustainable urban design today is challenged to create positive attitudinal shifts, to change social perceptions that green buildings are not merely a trend, and that sustainable architecture is a way of experiencing nature in environmental design. Practitioners need to cultivate and sustain stronger sustainability vision through continually thinking of ways to ramp up long-term solutions for creative integration of spatial designs, systems and materials with technological innovations purposed for the urban buildings of tomorrow.

\section{References}

Baird, G. (2014) 'User's perceptions of sustainable buildings: Key findings of recent studies' in Renewable Energy, 73: 77 - 83.
Berawi, M.A., Miraj, P., Windrayani, R. and Berawi, A.R.B. (2019) 'Stakeholders' perspectives on green building rating: A case study in Indonesia' in Heliyon, 5(3): e01328.

Berawi, M.A., Miraj, P., Windrayani, R. and Berawi, A.R.B. (2019) 'Stakeholders' perspectives on green building rating: A case study in Indonesia' in Heliyon, 5(3): e01328. [image]. Retrieved April 21, 2020, from https://ars.els-cdn.com/content/image/1-s2.0S2405844018343500-gr1.jpg

Bianchini, R (2019) Centre Pompidou Paris [image]. Retrieved April 27, 2020, from https://www.inexhibit.com/mymuseum/centrepompidou-paris/

Boonstra, C., Rovers, R. and Pauwels, S., eds. (2000) International Conference on Sustainable Buildings [Conference Proceedings, 22-25 October]. Maastricht, The Netherlands: Aeneas Publishers.

Brophy, V. and Lewis, J.O. (2011) A Green Vitruvius: Principles and Practice of Sustainable Architectural Design. $2^{\text {nd }}$ ed. London: Earthscan Ltd.

Brundtland Report (1987) Our Common Future. Oslo, Norway: United Nations World Commission on Environment and Development, WCED. Retrieved from: http://www.un-documents.net/ourcommon-future.pdf. Retrieved on May 24, 2020

Chan, A.P.C., Darko, A., Ameyaw, E.E. and Owusu-Manu, D.G. (2017) 'Barriers Affecting the Adoption of Green Building Technologies in Journal of Management in Engineering, 33(3): 37-48 October. ASCE.

Chapman, J. and Gant, N. (2012) Designers, Visionaries and Other Stories: A Collection of Sustainable Design Essays. London: Earthscan Ltd.

Circular Ecology (n.d.) Sustainability And Sustainable Development - What Is Sustainability And What Is Sustainable Development?. Retrieved from: http:/ / www.circularecology.com/sustainability-and-sustainabledevelopment.html\#.XjfLBTIzbIV. Retrieved on March 16, 2020

Chatterjee, A., ed. (2014) Surface and Deep Histories: Critiques and Practices in Art, Architecture and Design. Newcastle-upon-Tyne: Cambridge Scholars Publishing.

Cooke, R., Cripps, A., Irwin, A. and Kolokotroni, M. (2006) 'Alternative Energy Technologies in Buildings: Stakeholder Perceptions' in Renewable Energy, 32(14): 2320-33.

Curwell, S. R., Deakin, M. and Symes, M. (2007) Sustainable Urban Development: Environmental Assessment Methods. 2. London: Taylor \& Francis.

Czerwinska, D. (2017) Improving the lives of billions by helping to achieve the UN Sustainable Development Goals. World Green Building Council. Retrieved from: https://www.worldgbc.org/newsmedia/green-building-improving-lives-billions-helping-achieve-unsustainable-development-goals. Retrieved on March 08, 2020

Dovey, K. (2007) Framing Places: Mediating Power in Built Form. $2^{\text {nd }}$ ed. Abingdon, Oxon: Routledge.

Dovey, K. (2010) Becoming Places: Urbanism/Architecture/Identity/Power. Abingdon, Oxon: Routledge.

Fairs, M. (2013) 'Sorry green design, it's over'. Dezeen. February 14. Retrieved from: https://www.dezeen.com/2013/02/14/marcusfairs-sustainability-technology/ Retrieved on April 19, 2020 
Fairs, M. (2009) Green Design: Creative Sustainable Design for the TwentyFirst Century. London: Carlton Books Ltd.

First Unitarian Society Landmark Auditorium. (n.d.) [image]. Retrieved March 02, 2020, from https://fusmadison.org/welcome/meeting-house/

Groat, L.N. and Wang, D. (2013) Architectural Research Methods. $2^{\text {nd }} e d$. Hoboken, N.J.: John Wiley.

Halbersberg, E. (2012) Building A New Port. interiors + sources. August 27. Retrieved from: https://www.interiorsandsources.com/articledetails/articleid/14616/title/building-a-new-port Retrieved on February 27, 2020

Hanson, J. (2004) The Inclusive City: Delivering a more accessible urban environment through inclusive design. [Conference Proceedings] RICS Cobra. York, UK: International Construction Conference. Retrieved from: https://discovery.ucl.ac.uk/id/eprint/3351/. Retrieved on April 05, 2020

Hanzl, M. (2007) 'Information technology as a tool for public participation in urban planning: a review of experiments and potentials' in Design Studies, 28(7): 289-307.

Horman, M.J., Riley, D.R., Lapinski, A.R., Korkmaz, S., Pulaski, M.H., Magent, C.S., Luo, Y.P., Harding, N. and Dahl, P.K. (2006) 'Delivering Green Buildings: Process Improvements for Sustainable Construction' in Journal of Green Building, 1(1): 123-140. Retrieved from:https://www.journalofgreenbuilding.com/doi/pdf/10.3992/jg b.1.1.123. Retrieved on March 20, 2020

Imperiale, A. (2000) New Flatness: Surface Tension in Digital Architecture. Basel, Switzerland: Birkhauser.

Lane, E.L. (2011) Clean Tech Intellectual PropertY: Eco-Marks, Green Patents and Green Innovation. New York: Oxford University Press, Inc.

Legacy Solar Co-Op (2019) First Unitarian Society (FUS) of Madison. Retrieved from: https://legacysolarcoop.org/first-unitarian-societyfus-of-madison/ Retrieved on March 12, 2020

Lowe, N. (2010) Aesthetic Sustainability: The Fourth Bottom Line Orienting Sustainable Building and Development. Houston, Texas: Empire LLC.

Lott, M.C. (2015) Eiffel Tower Going Green With Two New Wind Turbines [image]. Retrieved February 13, 2020, from https://blogs.scientificamerican.com/plugged-in/eiffel-tower-goinggreen-with-two-new-wind-turbines/

Lynch, K. (2000) The Image of the City. Cambridge, MA: MIT Press.

Maczulak, A. (2010) Environmental Engineering: Designing A Sustainable Future. New York, N.Y.: Infobase Publishing.

McDonough, W. and Braungart, M. (2002) Cradle to Cradle: Remaking the Way We Make Things. New York: Farrar, Straus and Giroux.

Meinhold, B (2010) Green-Roofed Port of Portland Headquarters Aims for LEED Gold [image]. Retrieved April 05, 2020, from https: / /inhabitat.com/green-roofed-port-of-portland-headquartersaims-for-leed-gold/

Meyer, G. (2011) Exposing Infrastructure in the Works. Green Building Elements. March. Retrieved from: https://greenbuildingelements.com/2011/03/11/exposing-the- infrastructure/ Retrieved on April 07, 2020

Murphy, D. (2012) The Architecture of Failure. Winchester, UK: Zero Books.

Myers, G., Reed, R. and Robinson, J. (2007) The Relationship between Sustainability and the Value of Office Buildings. $13^{\text {th }}$ Pacific Rim Real Estate Conference. Perth, Australia: Curtin University of Technology. Retrieved from: http://prres.net/Papers/Myers_Reed_Robinson_The_Relationship_B etween_Sustainability.pdf Retrieved on March 04, 2020

O'Brien, L. (2011) Port of Portland Headquarters. Daily Journal of Commerce [DJC] Oregon. May 26. Retrieved from: https://djcoregon.com/news/2011/05/26/topprojects-port-ofportland-headquarters-submitted-by-zgf-architects-llp/ Retrieved on April 07, 2020

Oyedokun, T.B. (2017) 'Green premium as a driver of green-labelled commercial buildings in the developing countries: Lessons from the UK and US' in International Journal of Sustainable Built Environment, 6(2): 723-733.

Poyet, C. (2018) Discover the Centre Pompidou - Structural Colour [image]. Retrieved May 16, 2020, from https://www.guestviews.co/en/museum-guestviews-through-thepipes-of-centre-pompidou/

Proto, F. (2005) 'The Pompidou Centre: The hidden kernel of dematerialisation' in The Journal of Architecture, 10(5): 573-589.

Reed, R. and Lister, N.M. (2014) Ecology and Design: Parallel Genealogies. April. Places Journal. Retrieved from: https:/ / placesjournal.org/article/ecology-and-design-parallelgenealogies?cn-reloaded=1 Retrieved on February 15, 2020

Roche, S. (2014) 'Geographic Information Science I: Why does a smart city need to be spatially enabled?' in Progress in Human Geography, 38(5): 703-711.

Scientific American (2015) Eiffel Tower going green with two new wind turbines. March $6 . \quad$ Retrieved from: https://blogs.scientificamerican.com/plugged-in/eiffel-tower-goinggreen-with-two-new-wind-turbines/ Retrieved on March 26, 2020

Spiegel, R., Meadows, D. (2010) Green Building Materials: A Guide to Product Selection and Specification. $3^{\text {rd }}$ ed. Canada: John Wiley and Sons.

Skrzypaszek, P. (2018) First Unitarian Society Meeting House [image]. Retrieved March 24, 2020, from http: / / www.forconstructionpros.com/article/10686252/green-roofharmonizes-historic-church-designed-by-frank-lloyd-wright

Stake, R.E. (1995) The Art of Case Study Research. Thousand Oaks, CA Sage.

The Centre Pompidou (n.d.) The Building. Retrieved from: https://www.centrepompidou.fr/en/The-Centre-Pompidou/TheBuilding. Retrieved on March 26, 2020

Thompson, J.W. and Sorvig, K. (2008) Sustainable Landscape Construction: A Guide to Green Building Outdoors. $2^{\text {nd }}$ ed. Washington, DC: Island Press.

Trencher, G., Broto, V.C., Takagi, T., Sprigings, Z., Nishida, Y. and Yarime, M. (2016) 'Innovative policy practices to advance building 
energy efficiency and retrofitting: approaches, impacts and challenges in ten C40 cities' in Environmental Science Policy, 66: 353-365.

Whole Building Design Guide, WBDG (2016) Retrieved from: https://www.wbdg.org/resources/green-building-standards-andcertification-systems. Retrieved on May 10, 2020

World Green Building Council (n.d.) Retrieved from: https://www.worldgbc.org/ Retrieved on March 18, 2020

Woolley, T., Kimmins, S., Harrison, P. and Harrison, R. (2005) Green Buildings Handbook: A Guide to Building Products Impact on the Environment. Vol 1. London: Spon Press.

Wright on the Web (n.d.) Seventeen Buildings Honored by the American Institute of Architects. Retrieved from: https://www.wrightontheweb.net/his-works/17-buildings/

Retrieved on February 15, 2020

University of Wisconsin (2016) The Unitarian Meeting House (1951). Retrieved

from:

https:// wisc.pb.unizin.org/franklloydwright/ chapter/the-unitarian-

meeting-house-1951/. Retrieved on March 18, 2020

US Chamber of Commerce Foundation (2017) A Circular Vision for Sustainable Growth: How Companies are Building a New 21 $1^{\text {st }}$-Century Economy. June 28.2 Retrieved from: https://www.uschamberfoundation.org/best-practices/circularvision-sustainable-growth-how-companies-are-building-new-21st- century. Retrieved on April 23, 2020

van den Bergh, J.C.J.M. and Janssen, M.A. eds. (2004) Economics of Industrial Ecology: Materials, Structural Change and Spatial Scales. Cambridge, MA: MIT Press.

Van Leeuwen, J.P. and Timmermans, H.J.P., eds. (2006) Innovations in Design and Decision Support Systems in Architecture and Urban Planning. The Netherlands: Springer.

Yazan, B. (2015) Three Approaches to Case Study in Education: Yin, Merriam and Stake. The Qualitative Report, 20(2): 134-152. Retrieved from: https://nsuworks.nova.edu/tqr/vol20/iss2/12/. Retrieved on February 01, 2020

Yin, R. (1994) Case Study Research: Design and Methods. $2^{\text {nd }}$ ed. Newbury Park, CA: Sage.

Yudelson, J. and Meyer, U. (2013) The World's Greenest Buildings: Promise versus Performance in Sustainable Design. New York, N.Y.: Routledge.

Zainordin, N., S.M. Abdullah and Zarita Ahmad (2018) 'Users' Perception towards Energy Efficient Buildings' in Asian Journal of Environment Behaviour Studies, 3(6), Jan/Feb: 201-211. Retrieved from: https://aje-bs.e-iph.co.uk/index.php/ajE-Bs/article/view/250/227 Retrieved on February 09, 2020 